\title{
The Effect of Utilizing the Academic Information System as a Human Resource Development Strategy at the Global Era
}

\author{
Agus Suryanto $^{1}$, Totok Sumaryanto ${ }^{2}$, Fakhruddin $^{3}$ and Titi Prihatin ${ }^{4}$ \\ ${ }^{1}$ UNNES, Semarang
}

\begin{abstract}
Keywords: Augmented Reality, media, biology.
Abstract: $\quad$ Education providers should have skills and competencies that are good enough to meet the needs of the 21st century. To realize skilled human resources in the global era, capacity building in the field of information technology is needed. This study aims to determine the effect of information system utilization on individual performance with ease of use as a moderating variable. The population of this study is the Lecturers and Employees of the Faculty of Engineering, UNNES, which numbered 169 respondents, the sampling method used purposive sampling, while the samples that met the criteria amounted to 138 respondents. The results of the study show that the variable utilization of integrated academic information system has a significant positive effect on individual performance. While the ease of use variables does not moderate the effect of using this information system on individual performance, so the ease of use variable is not a moderating variable.
\end{abstract}

\section{INTRODUCTION}

The global era requires the management of information is something that is needed by every social government institution or including educational institutions. The institutional development of UNNES became an international standard conservation university that was healthy, superior, and prosperous, needed to be supported by an Information and Communication Technology Management Information System. Information technology can be defined as a combination of computer technology and telecommunications with other technologies such as hardware, software, databases, network technology, and other telecommunications equipment (Maharsi 2000). Furthermore, information technology is used in organizational information systems to provide information for users in the context of decision making.

Bodnar and Hopwood (1995) state that there are aspects that must be considered in implementing the Management Information System so that the success of the development of ICT-based SIM is achieved as follows: (1) hardware (software), software (users) and users (users). The Management Information Systems at UNNES include academic, administrative, staffing, and student licenses. $526 / 5000$

Research by Brynjolfsson and Hitt (1996) provides empirical evidence that investment in information technology can contribute positively to individual performance and company productivity. The use of sophisticated computer-based information technology enables management to implement information systems that can provide information that is oriented to help managers make managerial decisions and staff to complete tasks assigned by the organization to them. Sutabri (2005), said that a management information system is related to information. The use of information can be about raw data and structured data, the capacity of a communication channel. Therefore, lecturers, employees, and students are required to have special expertise in carrying out their activities using the management information system. Through the use of Informatic System, it will indirectly require users, in this case the entire campus consists of students, lecturers, and employees to be able to use Information and Communication Technology (ICT) based Management Information Systems. The researcher raised this title to determine the effect of information and management systems in improving the skills and abilities of lecturers, employees, and students in operating computer-based information technology in the global era. 
In this study using empirical studies at the Faculty of Engineering, Semarang State University. This is because in the Engineering Faculty there are Information and Communication Technology Education study programs related to Information System Technology. Samples in the study were individuals who worked at the Faculty of Engineering UNNES consisting of Lecturers and Employees of the Faculty of Engineering UNNES, taking into account the Lecturers and Employees of the Faculty of Engineering UNNES had more experience and knowledge about the Information System compared to other Faculties at UNNES.

UNNES as one of the state universities has used information technology. Information technology is used as a tool for efficiency and effectiveness in the management of UNNES. The utilization of information technology at UNNES has undergone development. Before 2004 the use of information technology at UNNES was limited to using computers using Microsoft Office programs (Microsoft Word, Microsoft Excel, Power Point and others). Since 2004 at UNNES has made an integrated academic information system.

\section{METHOD}

This research uses a qualitative approach. Data analysis techniques from this study were carried out using the Ward and Peppard (2002) framework. These stages consist of stages of data collection, analysis process, and output stages.

This stage is not just data collection but also classifies data into internal and external data of the organization. Data collection is done by interviewing, distributing questionnaires, observing and studying documentation.

The population in this study were users of the Integrated Academic Information System in the Faculty of Engineering UNNES which consisted of Students, Lecturers, and Employees. In conjunction with individual performance in this study using the population of lecturers and employees only. The number of Unnes Management Information System User Lecturers in the Engineering Faculty was 169, consisting of 39 people from the Electrical Engineering Department, 50 people from the Civil Engineering Department, 35 people from the Mechanical Engineering Department, 38 from the Technology Services \& Production Lecturers and 7 from the Chemical Engineering Lecturer. While the Unnes Management Information System user employees are 29 employees of the academic section in the Faculty of Engineering. So that the total population is 198 people.

In this study there are 3 types of variables consisting of independent variables, dependent variables and moderating variables. Independent variables are types of variables that explain or influence other variables. The independent variable in this study is the utilization of the information management system. While the dependent variable is the type of variable that is explained or influenced by the independent variable. The dependent variable in this study is individual personal ability. Moderating variable is a variable that strengthens or weakens the direct relationship between the independent variable and the dependent variable. The moderating variable in this study is ease of use.

\section{RESULTS AND DISCUSSION}

Respondents in this study were lecturers and employees of Unnes Management Information System users of the Faculty of Engineering, Semarang State University. The total questionnaires sent were 138 questionnaires. Returning questionnaires as many as $97(70.29 \%)$ including 4 completed questionnaires were incomplete, so the questionnaire that could be processed was 93 (67.39\%). The Unnes Management Information System is shown in figure 1.

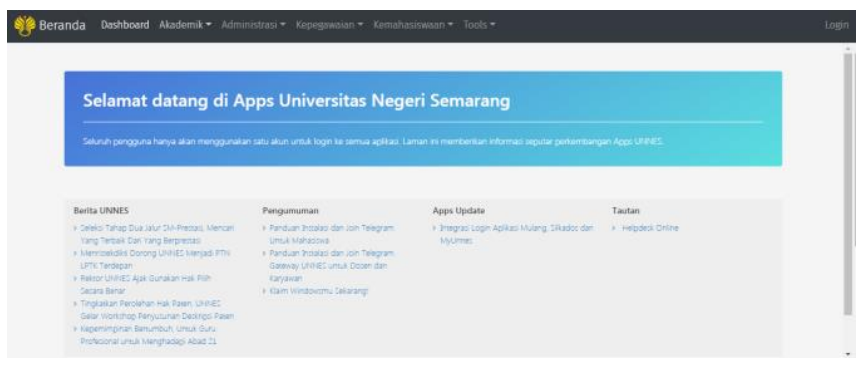

Figure 1. Unnes Management Information)

\subsection{Reliability Test}

To measure reliability with Cronbach Alpha test statistics. A construct or variable is said to be reliable if it gives an Cronbach alpha value> 0.60 (Nunnaly, 1967) (in Ghozali 2006). The following are the reliability test results shown in table 1. 
indicators of Unnes Management Information

Table 1. Reliability Test Results

\begin{tabular}{|c|l|c|c|}
\hline No & \multicolumn{1}{|c|}{ Variable } & $\begin{array}{c}\text { Nilai } \\
\text { Cronbach } \\
\text { Alpha }\end{array}$ & Information \\
\hline 1 & $\begin{array}{l}\text { Utilization of the } \\
\text { UNNES } \\
\text { Management } \\
\text { Information } \\
\text { System }\end{array}$ & 0,664 & Reliabel \\
\hline 2 & $\begin{array}{l}\text { User Personal } \\
\text { Capabilities }\end{array}$ & 0,855 & Reliabel \\
\hline 3 & $\begin{array}{l}\text { Ease of Use of the } \\
\text { UNNES } \\
\text { Management } \\
\text { Information } \\
\text { System }\end{array}$ & 0,887 & Reliabel \\
\hline
\end{tabular}

\subsection{Validity Test}

To test whether each indicator is valid or not can be seen in the display of Cronbach Alpha output in the Correlated Item - Total Correlation column both on UNNES Management Information System utilization constructs, individual performance and ease of use of Unnes Management Information System. Then the value of the Correlated Item Total Correlation is compared with the calculation result of $r$ table $=0.204$, if $r$ count $>r$ table and is positive then the item or question is declared valid. Validity test result shown in table 2.

Table 2. Validity Test Result

\begin{tabular}{lc}
\hline Indicators Construct & $\begin{array}{c}\text { Corrected Item- } \\
\text { Total Correlation }\end{array}$ \\
\hline Utilization 1 & .537 \\
Utilization 2 & .549 \\
Utilization 3 & .353 \\
\hline Individual Performance 1 & .702 \\
Individual Performance 2 & .739 \\
Individual Performance 3 & .743 \\
\hline Ease of Use 1 & .468 \\
Ease of Use 2 & .654 \\
Ease of Use 3 & .810 \\
Ease of Use 4 & .784 \\
Ease of Use 5 & .756 \\
Ease of Use 6 & .722 \\
\hline
\end{tabular}

From table 2 it can be seen that the value of $r$ calculates Corrected Item-Total Correlation for
System utilization, individual performance and ease of use of Unnes Management Information System > from $r$ table 0.204 . So, it can be concluded that all indicators of Unnes Management Information System utilization, individual performance and ease of use of Unnes Management Information System are valid.

\subsection{Classic assumption test}

Statistical testing with regression analysis can be done considering that there is no violation of the classic assumption test. The classic assumptions include:

\subsubsection{Data Normality Test}

The normality test aims to test whether in the regression model, the independent variable and the dependent variable both have a normal distribution or not. Figure 1 below is the result of normality test data in the form of a histogram graph.

Histogram

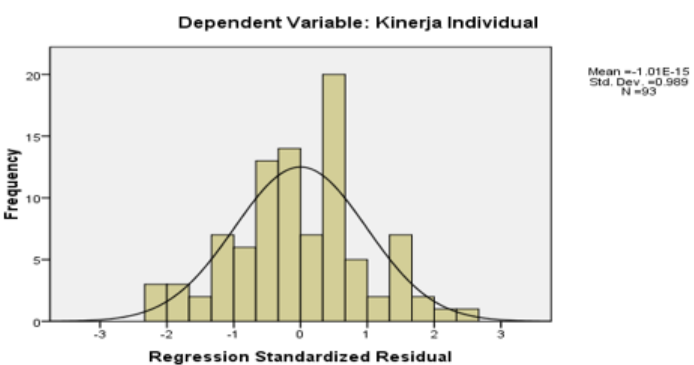

Figure 2. Histogram Graph

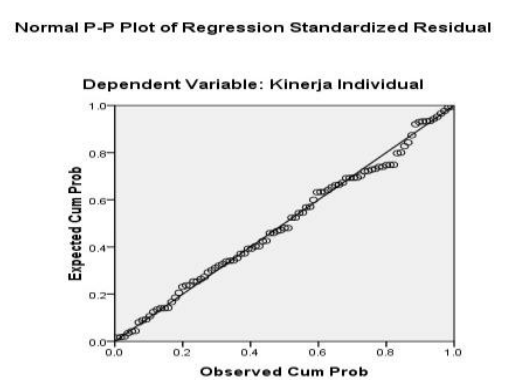

Figure 3. Normal Probability Plot Graph 
By looking at the histogram and normal plot graph display, it can be concluded that the histogram graph gives a normal distribution pattern. Whereas in the normal graph the plots appear to spread around the diagonal line and the spread follows the direction of the diagonal line. Both of these graphs show that the regression model meets the normality test.

\subsubsection{Multicollinearity Test}

Multicollinearity test aims to test whether the regression model found a correlation between independent variables. Multicollinearity can be seen from tolerance values and variance inflation factor (VIF). If the tolerance value below 0.10 or the variance inflation factor above 10 then occurs multicollinearity. A good model should not have a correlation between independent variables.

Table 3. Multicollinearity Test Results

\begin{tabular}{|c|c|c|c|}
\hline \multirow{2}{*}{$\begin{array}{c}\text { Independent } \\
\text { Variables }\end{array}$} & \multicolumn{2}{|c|}{ Collinearity Statistics } & \multirow[t]{2}{*}{ Decision } \\
\hline & Tollerance & $V I F$ & \\
\hline $\begin{array}{l}\text { Utilization of the UNNES } \\
\text { Management Information } \\
\text { System (X1) }\end{array}$ & .943 & 1.061 & $\begin{array}{l}\text { There is no } \\
\text { multicollinearity }\end{array}$ \\
\hline $\begin{array}{l}\text { Personal Ability of } \\
\text { Users of the } \\
\text { UNNES } \\
\text { Management } \\
\text { Information System } \\
\text { (X2) }\end{array}$ & .943 & 1.061 & $\begin{array}{l}\text { There is no } \\
\text { multicollinearity }\end{array}$ \\
\hline
\end{tabular}

The calculation result for tolerance indicates that there is no independent variable that has a toller of less than 0.10 which means there is no correlation between independent variables whose value is more than $95 \%$. The calculation of the Variance Inflation Factor (VIF) value also shows the same thing there is no one independent variable that has a VIF value of more than 10 . So, it can be concluded that there is no multicollinearity between independent variables in the regression model.

\subsubsection{Heteroscedasticity Test}

Heteroscedasticity test is used to test whether in a regression model there is an inequality of variance from the residual one observation to another observation. A good regression model is that homoskedasticity or heteroscedasticity does not occur. To detect the presence or absence of heteroscedasticity can be seen by looking at the plot graph between the predicted value of the dependent variable and the residual. Figure 4.3 below is the result of heteroscedasticity test in the form of a graph of scatterplots.

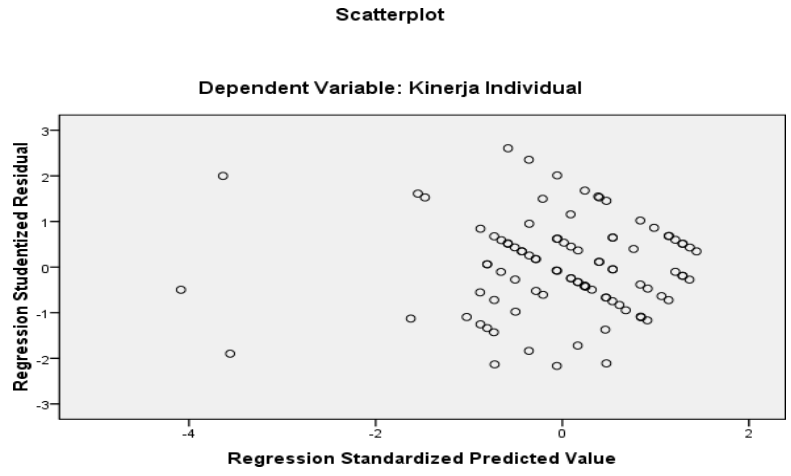

Figure 4. Scatterplots Graph

From the scatterplot graph it can be seen that the points spread randomly and spread either above or below the number 0 on the $\mathrm{Y}$ axis. This can be concluded that there is no heteroscedasticity in the regression model, so that a decent regression model is used to predict individual performance based on input independent variables utilization and convenience use of Unnes Management Information System.

\subsubsection{Effect of Unnes Management Information System Utilization on Individual Performance}

The results of testing the first hypothesis (H1) indicate that the use of Unnes Management Information System has a positive and significant effect on individual performance. The survey results show $9.7 \%$ to $38.7 \%$ of respondents use Unnes Management Information System with high intensity and frequency by using Unnes Management Information System menus that are more than 5 types. The survey results also showed $46.2 \%$ to $51.6 \%$ of respondents answered agreeing on each item questioning individual performance. While the results of statistical tests show that the effect of using Unnes Management Information System on individual performance has a positive effect of 2.179 at the 0.032 significance level, which means significant because it is below the required significance value of 0.05 . This shows that the use of Unnes Management Information System has a significant positive effect on individual performance.

The results of testing hypothesis 1 also show that the level of Unnes Management Information System utilization in the UNNES FT environment if viewed from the intensity, frequency of use and type of menu used has a positive influence in improving or improving individual performance. 
from the responses of respondents to the variable utilization of Unnes Management Information System, the intensity of using Unnes Management Information System in one day is mostly 30-60 minutes $(41.9 \%)$. So that it can be said that the intensity of the respondents' cyclic use in one day is low. Respondents' responses to the frequency of using Unnes Management Information System were mostly once or twice a week $(38.7 \%)$. So that it can be said that the frequency of the use of Unnes Management Information System respondents is low. It can be concluded that the use of Unnes Management Information System respondents is low. Although the use of Unnes Management Information System is easy, the intensity and frequency of Unnes Management Information System use is low. This might be due to respondents using Unnes Management Information System because of mandatory obligations, not paying attention to the ease of use of Unnes Management Information System. Thus the ease of use of Unnes Management Information System will not affect the respondent's attitude towards the utilization of the Unnes Management Information System.

The results of statistical tests show that the regression coefficient moderating ease of use of cyclic -0.008 , the value of $t$ count is -0.039 with a significant value of 0.969 , so it can be interpreted that there is no significant influence on the ease of use of Unnes Management Information System on the relationship between the use of integrated academic information systems and individual performance .

The easier the use of Unnes Management Information System, the Unnes Management Information System utilization rate is not higher and the individual performance is also not higher. Conversely the more difficult the use of Unnes Management Information System then the level of Unnes Management Information System utilization is not lower and individual performance is also not getting lower. Easy or not use of Unnes Management Information System does not affect the relationship between Unnes Management Information System utilization and individual performance. This is due to the fact that the respondents consisting of Lecturers and Employees are indeed required to use Unnes Management Information System, because most of the Unnes Management Information System menus include information on class schedules, teaching schedules for lecture grades, student guardianship, Lecturer portfolio, KRS / KHS printing, recap print results studies, and various other menus must be used as long as they work according to their needs. Judging

\section{CONCLUSIONS}

From the results of testing the regression analysis and testing the absolute difference value it can be concluded that Unnes Management Information System utilization has a significant positive effect on individual performance.This shows that high intensity Unnes Management Information System utilization can improve individual performance.

The ease of use of Unnes Management Information System does not moderate the effect of Unnes Management Information System utilization on individual performance, so it can be concluded that the ease of use of Unnes Management Information System is not a moderating variable. This shows that easy or difficult use of Unnes Management Information System does not affect Unnes Management Information System utilization of individual performance.

\section{REFERENCES}

Bodnar, G.H. and William, S.H. (1998). Accounting Information System. 7th edition. Upper Saddle River. New Jersey: Prentice-Hall International, Inc.

Brynjolfsson, E. and Hitt. L. (1996). Paradox Lost? Firm Level Evidence on The Returns to Information's 
System. Management Science, 42(4), 541-558

Ghozali, I. (2006). Aplikasi Analisis Multivariate Dengan Program SPSS. Semarang: UNDIP.

Maharsi, S. (2000). Pengaruh Perkembangan Teknologi Informasi Terhadap Bidang Akuntansi Manajemen. Jurnal Akuntansi \& Keuangan, 2(2), 127-137.

Sutabri, Tata. (2005). Sistem Informasi Manajemen. Yogyakarta: Andi.

Ward, J. \& Peppard, J. (2002). Strategic Planning for Information System (2nd ed.). USA: John Wiley \& Sons. 